\title{
Prevention of falls in old people - a review
}

\author{
Magnus K. Karlsson, Caroline Karlsson, Maria Cöster, Håkan Magnusson and Björn E. Rosengen \\ Clinical and Molecular Osteoporosis Research Unit, Lund University, Malmö, Sweden
}

\section{Summary}

Physical training, if including specific different training modalities, reduces the fall risk in healthy communitydwelling older people, as does a home hazards modification programme. Vitamin D supplementation in older individuals with low levels of vitamin D, adjustment of psychotropic medication, and structured modification of multi-pharmacy are all drug-focused programmes that reduce the number of falls. Antislip shoe devices during icy conditions for older people who walk outdoors and multifaceted podiatry in patients with specific foot disability reduce the fall risk. First eye cataract surgery and pacemakers in patients with cardio-inhibitory carotid sinus hypersensitivity are surgical interventions that reduce the fall risk. Multifactorial preventive programmes that include training, both individually designed and generally prescribed, also reduce the fall frequency. With this in mind, we ought to initiate fall preventive programmes in older people, especially in high- risk groups, to reduce the number of falls and fallers in society.

Key words: epidemiology, falls, older people, prevention, randomized controlled trial.

\section{Introduction}

The number of fragility fractures has risen during the last 50 years $^{1}$ so that the worldwide prevalence in adults above the age of 50 years is 9.0 million, of which 1.6 million are of the hip, 1.7 million the forearm and 1.4 million clinically diagnosed vertebral fractures. ${ }^{2}$ The increase is estimated to continue, so that by the year 2050 there will be 6.3 million hip fractures globally, half of these in $\mathrm{Asia}^{3}$ (Fig. 1). This will impose a significant health care burden worldwide. ${ }^{1}$ Therefore we must introduce measures that reduce the number of falls and fractures.

Falls are commonly found in older people. One-third of community dwellers aged over

Address for correspondence: Magnus Karlsson, Department of Orthopaedics, Skåne University Hospital, SE-205 02 Malmö, Sweden.

Email: magnus.karlsson@med.lu.se
65 years and $60 \%$ of individuals in nursing and retirement homes fall each year. ${ }^{4}$ Furthermore, women fall more often than men. ${ }^{4}$ Falls are also often followed by pain syndromes, functional limitations, dislocations, serious soft tissue injuries, fractures, high healthcare costs and high mortality. 5 About $15 \%$ of falls in patients living in the community ${ }^{4}$ and $20 \%$ in institutionalized patients ${ }^{6}$ result in a significant injury, and $12 \%$ of all falls in older people are followed by a fracture. ${ }^{7}$ In addition, 23\% of trauma-related deaths in patients above age 65 years and $34 \%$ in those above age 85 years follow a fall. ${ }^{8}$

Fractures may provide the largest healthcare burden among fall-related injuries. ${ }^{9}$ Fragility fractures, i.e. fractures of the proximal humerus, distal forearm, vertebrae, pelvis, hip and the tibial condyles in older individuals due to low-energy trauma share common features, such as having a higher incidence in women than in men and an exponential increase with age. ${ }^{10}$ The incidence of hip fractures has increased during the last 50 years $^{1,11}$ even if in many western countries there has been a decline in the incidence since the end of the twentieth century. ${ }^{1,11}$ Despite this, the total number of hip fractures is still increasing due to changes in population demographics. As the proportion of older people in the population is due to grow even larger, the total number of fragility fractures will continue to rise, ${ }^{3}$ a fact that increases the need of fall- and fracture-reducing interventions. As a fall is one of the most striking risk factors for fractures, and as there exists strong evidence supporting the effectiveness of several fall preventive strategies, this review summarizes the fall prevention programmes that have been shown to have beneficial effects in randomized controlled trials (RCTs).

\section{Search methods}

We identified potentially interesting studies through a structured search in PubMed from all years by using the terms: 'accidental falls', 


\section{Hip Fractures Worldwide 1990 and 2050}

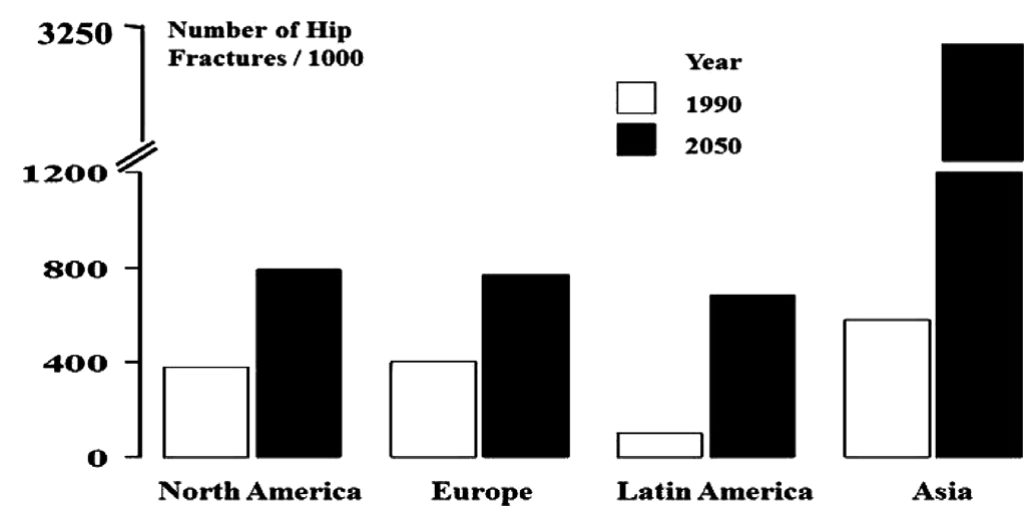

Figure 1. Estimated number of hip fractures in four geographic regions in 1990 and $2050^{3}$

'physical therapy', 'equipment', 'supplies', 'selfhelp devices', 'protective devices', 'environmental intervention', 'home modification', 'exercise', 'exercise therapy', 'physical education' and 'training'. From the identified studies, we included only those studies which, using RCTs, evaluated the effects of interventions designed to reduce falls in older people (individuals aged 60 years or more or described as elderly, seniors or older). The participants had to be living in the community at home or in places of residence that did not provide residential health-related care. Trials that included younger participants, for example those recruited on the basis of a medical condition such as a stroke or Parkinson's disease were only included if the mean age minus one standard deviation was more than 60 years. Some references found evaluated interventions in nursing care facilities or hospitals, but these data are presented separately. In studies with participants living in different settings, participants were included only if data were provided for subgroups based on setting. Intervention programmes were compared with 'usual care' or 'placebo'. Studies that evaluated two types of fall-prevention interventions were also included. Finally, we went through the included studies and excluded those without end-point variable rate or number of falls or number of participants sustaining at least one fall during follow-up (fallers). Apart from these studies, we also included recently published structured reviews and Cochrane reviews within the field that summarized the outcome in published RCTs. ${ }^{12-20}$ We chose to present central studies reported in these Cochrane reviews in the figures; that is, not all of the total of 159 RCTs reported in the latest Cochrane review are included in the figures, while additional reports could be referred to in the text. Finally, we also reviewed the reference lists of each to identify papers fulfilling the above-mentioned criteria to add further relevant RCTs.

The meta-analyses calculations referred to in this paper are published in detail in cited Cochrane reviews. ${ }^{12-14}$ In summary, in the meta-analyses, data from different RCTs with comparable interventions and participant characteristics were pooled by use of a generic inverse variance method. Calculated pooled rate ratios for total number of falls or risk ratios for being a faller with $95 \%$ confidence intervals were estimated through the fixed-effect model. Where there was substantial statistical heterogeneity, data were pooled using a random effect model. ${ }^{21}$

\section{Exercise}

Physical training in community-living old individuals reduces the risk of falling ${ }^{12,13,19,22-49}$ (Fig. 2) and is generally accepted as the most effective fall-prevention strategy in the community-living population. ${ }^{50,51}$ Exercise has also been reported as the most cost-effective fall-preventive strategy. ${ }^{13,14}$ Among the different training strategies, multicomponent exercise programmes that include balance training and muscle-strength training have been the most effective interventions, followed by flexibility and endurance training. ${ }^{13,14}$ The 
Multi-component exercise on group bases versus control

$\begin{array}{lrr}\text { Eallard 2004 } & 20 & 19 \\ \text { Barnett 2003 } & 76 & 74 \\ \text { Buchner 1997a } & 70 & 30 \\ \text { Bunout 2005 } & 111 & 130 \\ \text { Carter 2002 } & 40 & 40 \\ \text { Korpelainen 2006 } & 84 & 76 \\ \text { Lord 1995 } & 75 & 94 \\ \text { Lord 2003 } & 259 & 249 \\ \text { Luukinen 2007 } & 217 & 220 \\ \text { Means 2005 } & 144 & 94 \\ \text { Rubenstein 2000 } & 31 & 28 \\ \text { Skelton 2005 } & 50 & 31 \\ \text { Suzuki 2004 } & 22 & 22 \\ \text { Weerdesteyn 2006 } & 30 & 28\end{array}$

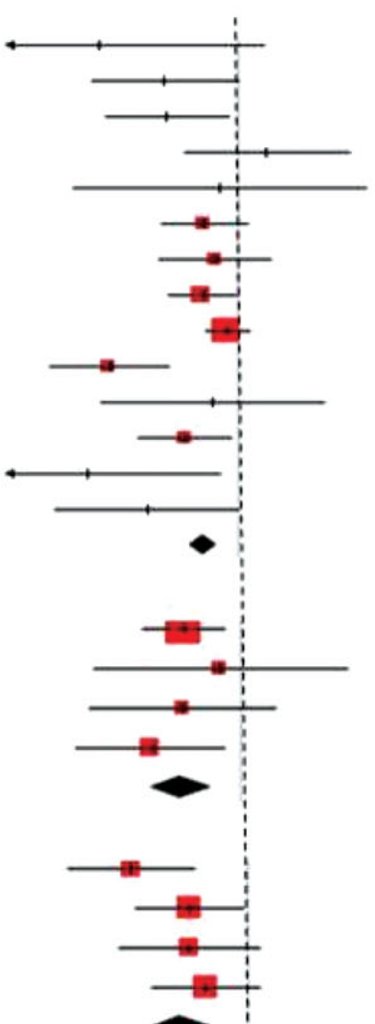

$0.38[0.12,1.20]$

$0.60(0.36,1.00\}$

$0.61[0.40,0.94]$

$1.22[0.69,2.16]$

$0.88(0.32,2.43)$

$0.79(0.59,1.06)$

$0.85[0.58,1.26)$

$0.78[0.62,0.99]$

$0.93(0.80,1.09)$

$0.41(0.27,0.62)$

$0.84(0.39,1.81)$

$0.69(0.50,0.96)$

$0.35[0.14,0.88\}$

$0.53[0.28 .1 .00]$

Subtotal (95\% Cl)

Multi-component exercise on individual bases inn home versus control

$\begin{array}{lrr}\text { Campbell 1997 } & 116 & 117 \\ \text { Campbell 1999 } & 45 & 48 \\ \text { Lin 2007 } & 50 & 50 \\ \text { Robertson 2001 a } & 121 & 119\end{array}$

Robertson 2001 a

50

Subtotal ( $95 \% \mathrm{Cl})$

Group Tai Chi exercise versus control

$\begin{array}{lrr}\text { Li } 2005 & 95 & 93 \\ \text { Voukelatos } 2007 & 347 & 337 \\ \text { Wolf } 1996 \text { (1) } & 72 & 64 \\ \text { Wolf } 2003 & 145 & 141\end{array}$

Subtotal (95\% Cl)

Group gait, balance and functional exercise versus control

Cornillon 2002

Liu-Ambrose 2004

M cMurdo 1997

150

32

Subtotal (95\% Cl) 
training should be performed often and with high frequency. ${ }^{25,44}$ Group training, where at least two different training components are included, has, in community-living old people above age 60 years decreased the fall rate by $22 \%$ (relative risk (RR) $0.78,95 \%$ confidence interval (CI) $0.71-0.86)$ and the risk of falling by $17 \%$ (RR $0.83,95 \%$ CI 0.72-0.97) (Fig. 2). Training classes that included gait balance alternating with functional training significantly reduced rate of falls by $27 \%$ (RR 0.73, 95\% CI 0.54-0.98) (Fig. 2). RCTs comparing different types of exercise or methods of delivery have not found any differences. ${ }^{13}$

Individually designed exercise programmes with more than one exercise modality, conducted at home, is another approach that reduces the number of falls in community-living old individuals by $34 \%$ (RR 0.66, 95\% CI 0.53-0.82) and the risk of falling by $23 \%$ (RR 0.77 , 95\% CI $0.61-0.97)^{13}$ (Fig. 2). However, training can be beneficial even if using only one exercise modality. Such an example is Tai Chi training where the beneficial effects include both strength and balance training. In the general old population this type of training reduced the number of fallers by close to $50 \%$ in one RCT published by the FICSIT group (Frailty and Injuries: Co-operative Studies of Intervention Techniques) $)^{52}$ and a meta-analysis that included unselected community-living older people supported this notion when reporting that Tai Chi reduced the number of falls by $37 \%$ (RR 0.63 , 95\% CI 0.52-0.78) and the number of fallers by $35 \%$ (RR $0.65,95 \%$ CI $0.51-$ 0.82) (Fig. 2). The beneficial effect is usually referred to the fact that Tai Chi includes both strength and balance training. ${ }^{53}$ Another recent published RCT showed that home-based balance and strength training in older community-living individuals aged 70 years or older, who had two or more falls or one injurious fall in the past 12 months, was followed by a $31 \%$ reduction in the number of falls (RR $0.69,95 \%$ CI $0.48-0.99$ ). ${ }^{54}$ A music-based multi-task exercise programme in community-dwelling individuals older than 65 years who were at increased risk of falling was also effective, and the programme resulted in $54 \%$ fewer falls in the exercise group (RR 0.46; $95 \%$ CI $0.27-0.79) .55$ The authors concluded that functional-based exercise should be a focus for interventions to protect older, high-risk individuals from falling and that the effect of physical training as a fall reductive strategy is less effective in institutionalized individuals. ${ }^{12,56-62}$ (Fig. 3). Supervised training in institutionalized individuals above age 65 years reduced the risk of falling by $56 \%$ (RR $0.44,95 \%$ CI $0.20-0.97)^{12}$ in one metaanalysis, but further subgroup analyses showed that the positive effect was only found in older people in sub-acute care hospitals, and not in those staying in general nursing care facilities ${ }^{12}$ (Fig. 3). However, it should be noted that gait, balance and co-ordination exercises utilizing a mechanical apparatus in individuals in nursing homes did reduce the rate of falls by $55 \%$ (RR $0.45,95 \%$ CI $0.24-0.85)$. Therefore, we cannot exclude that specific types of training in specific groups actually can reduce the fall frequency also in older individuals staying in nursing homes or other type of institutions (Fig. 3).

\section{Vitamin D}

Vitamin D supplements provided to unselected community-living older people did not reduce the number of falls (RR $0.95,95 \%$ CI 0.80 1.14) (Fig. 4). ${ }^{13,14,63-69}$ Slightly more positive conclusions could be drawn when the supplement was given to institutionalized old individuals, where the total number of falls was reduced by $28 \%$ (RR 0.72, 95\% CI 0.55-0.95) (Fig. 4). ${ }^{12}$ In old people with low vitamin D levels, the subgroup analyses revealed that the number of falls was reduced by $43 \%$ (RR 0.57 , 95\% CI $0.37-$ 0.89 ) (Fig. 4), as was the number of fallers by $35 \%$ (RR 0.65, 95\% CI 0.46-0.91). ${ }^{66,68}$ No fall reduction was seen in old people with normal vitamin D levels. However, the type of supplement also seems to be of importance, as calcitriol reduced the number of falls by $36 \%$ (RR $0.64,95 \%$ CI $0.49-0.82)^{67}$ while alfacalcidol did not (RR 1.08, $95 \%$ CI $0.75-1.57)^{70}$ (Fig. 4). Vitamin D supplements may reduce the number of falls but probably only in those with low vitamin D levels and maybe only with specific types of vitamin D drugs.

\section{Medication}

Multi-pharmacy and combinations of specific drugs may be associated with increased fall risk in the older population. A structured prescription modification programme could therefore hypothetically reduce the fall risk. One RCT demonstrated this in the intervention group, where a gradual 
Supervised exercise versus standard nursing care

$\begin{array}{lrr}\text { Faber } 2006 & 142 & 90 \\ \text { Mulrow } 1994 & 97 & 97 \\ \text { Rosendahl 2008 } & 87 & 96 \\ \text { Sakam oto 2006 } & 315 & 212 \\ \text { Schoenfelder 2000 } & 9 & 7 \\ \text { Shimada 2004 } & 15 & 11 \\ \text { Sihvonen 2004 } & 20 & 7\end{array}$

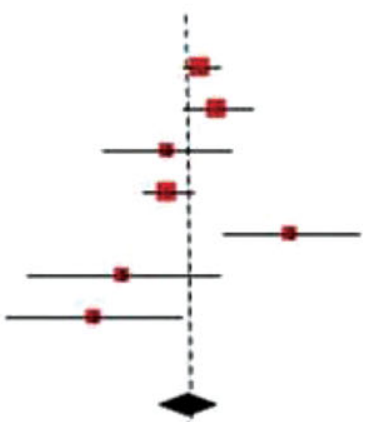

Total (95\% Cl)

$1.13[0.95,1.35]$

$1.32[0.95,1.85]$

$0.82(0.44,1.53)$

$0.82[0.65,1.04]$

$2.72[1.42,5.19]$

$0.53[0.21,1.34]$

$0.40[0.17,0.93]$

$1.00[0.74,1.35]$

Single exercise modalities - gait, balance and coordination using meachnical apparatus versus standard nursing care

$0.53[0.21,1.34]$

$0.40[0.17,0.93]$

Sihvonen 2004

11

Subtotal (95\% Cl)

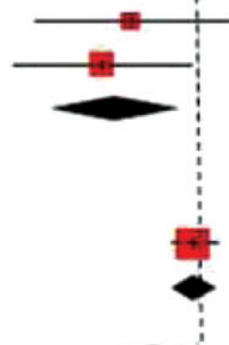

Combination of exercise modalities versus standard nursing care

Faber 2006

Mulrow 1994

Rosendaht 2008

Schoenfelder 2000

$\begin{array}{rr}64 & 90 \\ 97 & 97 \\ 87 & 96 \\ 9 & 7\end{array}$

90

78

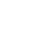


Vitamin D3 versus placebo

Latham 2003

108

114

Subtotal $(95 \% \mathrm{Cl})$

Vitamin D3 plus calcium versus placebo

Porthouse 2005

1125

Bischoff-Ferrari 2006

219

1877

226

Subtotal (95\% Cl)

Vitamin D3 plus calcium versus calcium

Pteifer 2000

70

Subtotal (95\% CI)

Vitamin D2 (injection) versus placebo

Dhesi 2004

62

Subtotal (95\% CI)

\section{Total $(95 \% \mathrm{Cl})$}

Vitamin D3 versus placebo in individuals with low vitamin D level at baseline

Dhesi 2004

Pfeifer 2000

62

70

Subtotal $(95 \% \mathrm{CI})$

Calcitriol (vitamin D analogue) versus placebo

Gallagher 2001

101

\section{Subtotal $(95 \% \mathrm{Cl})$}

Alfacalcitriol (vitamin D analogue) versus placebo

Sato 1999

40

Subtotal $(95 \% \mathrm{CI})$
61

67

67

61

112

40

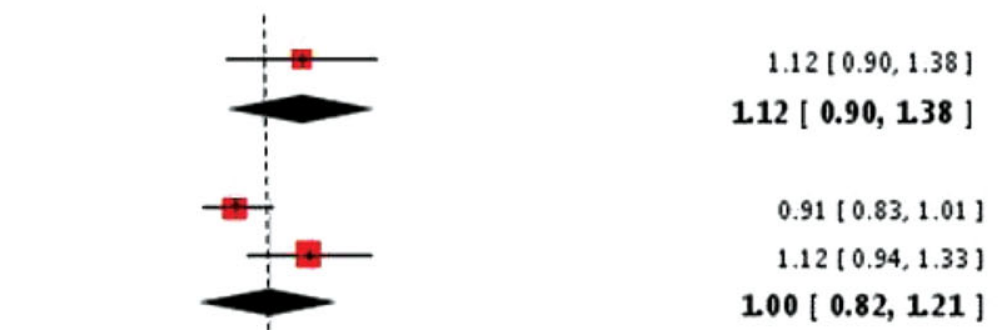

$0.54[0.30,0.98]$

$0.54[0.30,0.98$ ]

$0.61[0.32,1.17]$

0.61 [ $0.32,1.17$ ]

$0.95[0.80,1.14$ ]

$0.61[0.32,1.17]$

$0.54[0.30,0.98]$

0.57 [ $0.37,0.89$ ]

$0.64[0.49,0.82]$

0.64 [ $0.49,0.82$ ]

$1.08[0.75,1.57]$

1.08 [ $0.75,1.57]$

Favours intervention
0.2

0.5 
withdrawal of psychotropic medication resulted in a $66 \%$ reduction in the number of falls (RR 0.34 , 95\% CI 0.16-0.73) (Fig. 5). ${ }^{22}$ Fall preventive education for family physicians that included academic teaching, feedback on prescribing practices and financial rewards combined with self-assessment of medication followed by a medication review with modification of prescriptions in communitydwelling older people was found to reduce the risk of falling by $39 \%$ (RR $0.61,95 \%$ CI $0.41-0.91)^{71}$ (Fig. 5). Modification of prescriptions could also have an effect on individuals staying in institutions, since beneficial effects were found in one RCT that evaluated a prescribing modification programme by pharmacists in nursing care facilities or hospitals, an intervention that reduced the fall frequency by $38 \%$ (RR $0.62,95 \%$ CI $0.53-0.72$ ). ${ }^{22}$

\section{Surgery}

Surgical interventions may be effective in reducing falls in specific risk groups. Cardiac pacemakers, in patients with cardioinhibitory carotid sinus hypersensitivity, were in one published RCT reported to reduce the rate of falls by $58 \%$ (RR $0.42,95 \%$ CI $0.23-0.75$ ) (Fig. 5). ${ }^{72}$ Cataract surgery for the first eye was, in another RCT, found to reduce the rate of falls by $34 \%$ (RR $0.66,95 \%$ CI $0.45-0.95$ ) (Fig. 5). ${ }^{73}$ Cataract surgery for the second eye was, however, not associated with a reduced fall rate (RR 0.68, 95\% CI 0.39-1.17) ${ }^{74}$ (Fig. 5).

\section{Home hazards}

Modification of home hazards in the general older population reduce the number of falls (RR 0.81 , $95 \%$ CI $0.68-0.97$ ) (Fig. 6) and the number of fallers (RR 0.88 , 95\% CI 0.80-0.96). ${ }^{14,41,75-80}$ Modifications of home hazards in individuals above age 75 years with visual impairment that removed or changed loose floor mats, painted the edges of steps, reduced glare, installed grab bars and stair rails, removed clutter and improved lighting where needed, was followed by a $41 \%$ fall reduction (RR 0.59 , 95\% CI 0.42-0.83) (Fig. 6) and $24 \%$ reduction in number of fallers (RR 0.76 , 95\% CI 0.62-0.95). ${ }^{13,14,78}$ A pooled sub-group analysis revealed that a home safety programme reduced the fall risk by $44 \%$ (RR $0.56,95 \%$ CI $0.42-0.76$ ) (Fig. 6) and the number of fallers by $22 \%$ (RR $0.78,95 \%$ CI $0.64-0.95$ ) in highrisk individuals, such as individuals with a history of a fall or multiple risk factors. Home hazard assessment and modification of risk factors should therefore be provided to all older people, but particularly focused on high-risk individuals as the interventions seem more effective in people at higher risk of falling. ${ }^{14}$

\section{Footwear}

The type of footwear may influence the risk of falling. ${ }^{81}$ Anti-slip shoe devices have, in one study, been shown to reduce the rate of falls by $58 \%$ (RR 0.42, 95\% CI 0.22-0.78) (Fig. 5), but only in old individuals who walked outdoors during icy conditions ${ }^{82}$ (Fig. 5). Anti-slip shoe devices should therefore be recommended to ambulatory old people who walk outdoors under icy conditions and multifaceted podiatry to patients with specific foot disability. Another RCT that evaluated the effect of multifaceted podiatry including foot and ankle exercise found that this intervention reduced the fall risk by $36 \%$ (RR $0.64,95 \%$ CI $0.45-$ 0.91) (Fig. 5) compared with standard podiatry in patients with disabling foot pain. ${ }^{83}$

\section{Generalized multifaceted intervention}

Hypothetically, it ought to be beneficial to modify as many risk factors as possible. One approach would be to prescribe generally designed intervention programmes that include a fixed combination of different components of interventions that are delivered to all participants independently of individual demands. Examples of such programmes are those including exercise, care planning, medical and/or diagnostic approaches, changes in physical environment, education programmes, calcium and vitamin $\mathrm{D}$ supplementation, medication review and removal of physical restraints. ${ }^{12-14,18,78,84-87}$ (Fig. 7). Generalized programmes have, in RCTs, been found to reduce the fall rate by $31 \%$ when including exercise, education and a home safety intervention (RR $0.69,95 \%$ CI $0.50-0.96$ ), ${ }^{85}$ by $81 \%$ when including exercise plus nutritional supplementation in vitamin $\mathrm{D}$ and calcium replete women (RR 0.19 , 95\% CI $0.05-0.68),{ }^{87}$ by $24 \%$ when including exercise and home safety assessment (RR 0.76, 95\% CI $0.60-0.97$ ), ${ }^{80}$ by $27 \%$ when including exercise plus vision assessment (RR 0.73 , 95\% CI $0.59-0.91),{ }^{80}$ by 
Psychotropic medication withdrawal versus control Campbell 1999 (1)

48

45

Subtotal $(95 \% \mathrm{CI})$

GP educational program and medical review and modification versus control (fallers)

Pit 2007

350

309

Subtotal $(95 \% \mathrm{Cl})$

Cardiac pacing versus controls

Kenny $2001^{-}$

Parry 2009 (1)

Ryan 2010

Subtotal $(95 \% \mathrm{Cl})$

Cataract surgery (first eye) versus controls

Harwood 2005

154

152

Subtotal $(95 \% \mathrm{CI})$

Cataract surgery (second eye) versus controls

Foss 2006

120

119

Subtotal (95\% CI)

Anti-slip shoe device of icy conditions versus no intervention

McKiernan 2005 (2)

55

54

Subtotal $(95 \% \mathrm{CI})$

Multifacetet podiatry with foot and ankle training versus routine podiatric care

Spink $20111^{\circ}$
Subtotal $(95 \% \mathrm{CI})$

153

152

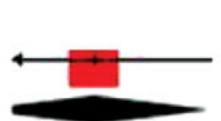

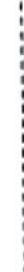
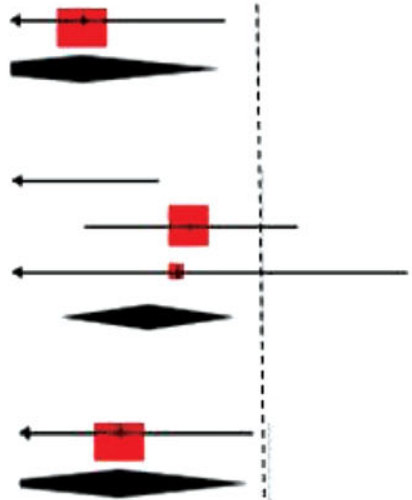

$0.66[0.45,0.95]$

$0.68[0.39,1.17]$ 0.68 | 0.39, 1.17 |

$0.42[0.22,0.78]$ $0.42[0.22,0.78]$

$0.64[0.45,0.91]$ 0.64 [ $0.45,0.91$ ]

Favours intervention

0.5 
Home safety versus no home safety

$\begin{array}{lrr}\text { Campbell 2005 (1) } & 198 & 193 \\ \text { Cum ming } 1999 & 264 & 266 \\ \text { Day 2002 (2) } & 543 & 547 \\ \text { Lin 2007 } & 50 & 50 \\ \text { Nikolaus 2003 } & 181 & 179 \\ \text { Stevens 2001 } & 570 & 1167\end{array}$

\section{Total (95\% Cl)}

Home safety versus no home safety in high risk individuals

$\begin{array}{lrr}\text { Campbell 2005 (1) } & 198 & 193 \\ \text { Lin } 2007 & 50 & 50 \\ \text { Nikolaus } 2003 & 181 & 179\end{array}$

Subtotal $(95 \% \mathrm{Cl})$

Home safety with occupational therapist versus no home safety

$\begin{array}{lrr}\text { Campbell 2005 (1) } & 198 & 193 \\ \text { Cumming } 1999 & 264 & 266 \\ \text { Nikolaus 2003 } & 181 & 179 \\ \text { Pighills 2011 (2) } & 85 & 77\end{array}$

Pighills $2011(2)$

85

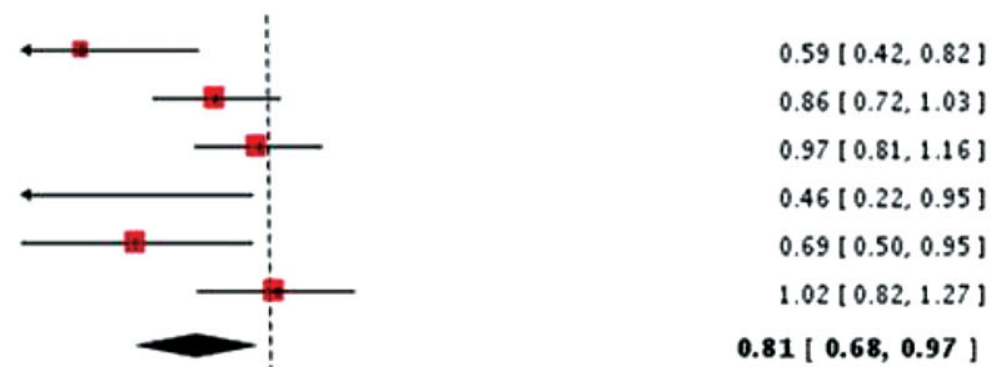

$0.59[0.42,0.82]$

$0.46[0.22,0.95]$

$0.69[0.50,0.95]$

$0.62[0.50,0.77]$

$0.59[0.42,0.82]$

$0.86[0.72,1.03]$

$0.69[0.50,0.95]$

$0.54[0.36,0.81]$

$0.69[0.55,0.86]$

Home safety versus no home safety in elderly with seve visual impairement

Campbell 2005 (1)

198

193

Subtotal $(95 \% \mathrm{Cl})$

$.59[0.42,0.82]$

0.59 [ $0.42,0.82$ ]

Visual assessment/eye examination with intervention if necessary versus no intervention

Cum ming 2007

309

307

Subtotal (95\% CI)

$1.57[1.19,2.06]$

1.57 [ 1.19, 2.06 ]

Favours intervention

\section{$n^{0.2}$}

0.5

25

Figure 6. Comparison of number of falls in community-living older people exposed to intervention with home hazard assessment followed by risk factor reduction versus controls reported in several RCTs 
Exercise and vitamin D versus no intervention in patients with visual impairment Campbell 2005 (1)

Subtotal $(95 \% \mathrm{Cl})$

\title{
Exercise and fall precentive advice versus no intervention
}

Hill 2000

40

38

\section{Subtotal $(95 \% \mathrm{Cl})$}

Exercise, education and risk assessment versus no intervention Shumway-Cook 2007

226

227

Subtotal $(95 \% \mathrm{Cl})$

Exercise, education and home saftety intervention versus no intervention

\author{
Clem son 2004
}

147

138

Subtotal $(95 \% \mathrm{CI})$

Exercise, nutrition, vitamin $\mathrm{D}$ and Calcium versus no intervention

Swanenburg 2007

10

10

Subtotal $(95 \% \mathrm{Cl})$

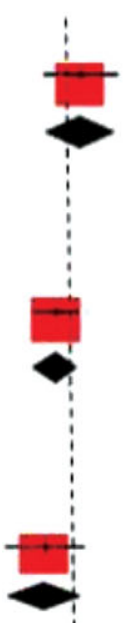

$1.15[0.82,1.61]$

1.15 [0.82, 161]

$0.89[0.71,1.10]$

$0.89[0.71,1.10]$

$0.75(0.52,1.09)$

$0.75[0.52,1.09]$

$0.69[0.50,0.96)$

0.69 [ $0.50,0.96$ ]

$0.19[0.05,0.68]$

0.19 [ $0.05,0.68$ ] 
Assessment of risk factors followed by multifactorial active intervention versus no intervention

Close 1999
Davison 2005
Hornbrook 1994
Lord 2005 (1)
Salm inen 2008
Tinetti 1994
Wym an 2005

$\begin{array}{rr}141 & 163 \\ 144 & 149 \\ 1611 & 1571 \\ 202 & 201 \\ 292 & 297 \\ 147 & 144 \\ 126 & 126\end{array}$

$0.41[0.34,0.49\}$ $0.64[0.46,0.89]$ $0.84[0.80,0.89)$ $1.03[0.78,1.36]$ $0.92(0.77,1.10)$ $0.56(0.42,0.75)$ $0.72(0.54,0.96)$ Subtotal (95\% Cl) 26

Assessment of risk factors followed by referral or information versus no intervention

$\begin{array}{lrr}\text { Carpenter } 1990 & 181 & 186 \\ \text { Elley 2008 } & 155 & 157 \\ \text { Gallagher 1996 } & 50 & 50 \\ \text { Hogan 2001 } & 75 & 77 \\ \text { Lightbody 2002 } & 155 & 159 \\ \text { Lord 2005 (2) } & 194 & 201 \\ \text { Mahoney 2007 } & 174 & 175 \\ \text { Rubenstein 2007 } & 337 & 352 \\ \text { Subtotal (95\% Cl) } & & \end{array}$

$0.34[0.18,0.65]$

$0.96[0.69,1.34]$

$0.81[0.60,1.09]$

$0.74[0.62,0.88]$

$0.85[0.69,1.06]$

$0.90[0.69,1.16]$

$0.81[0.57,1.15]$

$1.19[0.90 .1 .56]$

$0.84[0.72,0.98]$

Subtotal $(95 \% \mathrm{Cl})$ 
$23 \%$ when including exercise plus vision and home safety assessment (RR 0.67, 95\% CI 0.51$0.88)^{80}$ and by $23 \%$ when including educational intervention combined with free access to an assessment at a geriatric clinic (RR 0.77, 95\% CI $0.63-0.94)^{88}$ (Fig. 7).

\section{Individualized multifactorial intervention}

In individualized multifaceted intervention programmes, each individual would be evaluated for risk factors and then be assigned to an individually designed prevention programme $e^{13,14,21,89-101}$ (Fig. 8). Similar programmes have been shown to reduce the rate of falls in community-dwelling old adults by $25 \%$ (RR $0.75,95 \%$ CI $0.65-$ 0.86) (Fig. 8). ${ }^{13,14}$ In hospital settings, these multifactorial interventions reduced the rate of falls by $31 \%$ (RR 0.69 , 95\% CI 0.49-0.96) (Fig. 8) and the risk of falling by $27 \%$ (RR $0.73,95 \%$ CI $0.56-0.96)$. The number of falls was not reduced in individuals living in nursing home facilities (RR 0.82, 95\% CI 0.68-1.08), even if further sub-analysis revealed that specific types of interventions with multidisciplinary team approaches together with physical training reduced the rate of falling also in nursing home residents by $40 \%$ (RR 0.60, 95\% CI 0.5-0.72). ${ }^{12}$ It should also be noted that all multiple intervention trials that have been shown to reduce the fall risk include some type of physical training in the intervention ${ }^{12-14}$ (Fig. 8) and that multi-factorial risk assessment in conjunction with comprehensive management of identified risk factors are usually recommended to focus on high-risk populations. In the recently updated American Geriatric Society (AGS) clinical practice guidelines, this especially accounts for older adults who have sustained two falls or more in the recent year, have gait or balance problems or have presented with an acute fall.

\section{Interventions with harmful effects}

An intervention programme can also increase the fall rate. Two RCTs have reported that intervention with vision assessment, eye examination, new spectacles and/or ophthalmology treatment in conjunction with mobility training and canes increased the fall rate by $57 \%$ (RR $1.57,95 \%$ CI 1.19-2.06) $)^{77,80}$ (Fig. 6). Exercise in hospitalized individuals that included several different training modalities was in one RCT found to increase the fall rate by $172 \%$ (RR $2.72,95 \%$ CI $1.42-5.19)^{59}$ (Fig. 3) and when using pooled data from several RCTs that included different types of training modalities, by $37 \%$ in people in hospital settings (RR 1.37, 95\% CI 1.01-1.85) (Fig. 3). This highlights the importance of drawing inferences for fall preventive effect only in cohorts similar to the one evaluated in RCTs and not directly transfer the conclusion of beneficial effects in one cohort to other populations.

\section{Cost benefits}

In one review there were eight RCTs that included economic evaluation as an outcome. ${ }^{13,14}$ These studies infer that there is weak evidence that prevention strategies for fall reduction can be cost saving during the trial period, but also during the rest of the lifespan of the participants. All reports also infer that the prevention strategies with fallreducing effects ought to be targeted at high-risk sub-groups of old people to achieve greatest costbeneficial effects. ${ }^{13}$

\section{Conclusions}

Fall risk in community-living old individuals is reduced by:

- Regular exercise that includes multicomponent training modalities

- Reduction of home hazards

- Vitamin D supplements in individuals with low levels of vitamin D

- Adjustment of psychotropic medication

- Structured modification of multi-pharmacy

- Anti-slip shoe devices in older individuals walking outdoors during icy conditions

- Multifaceted podiatry to patients with specific foot disability

- First eye cataract surgery in patients with visual impairment

- Pacemakers in patients with cardioinhibitory carotid sinus hypersensitivity

- Generalized multifactorial fall prevention programmes

- Individually designed multifactorial fall prevention programmes. 


\section{Conflict of interest}

There are no competing interests for any of the authors.

\section{References}

1 Rosengren BE, Ahlborg HG, Mellstrom D, Nilsson JA, Bjork J, Karlsson MK. Secular trends in Swedish hip fractures 1987-2002: birth cohort and period effects. Epidemiology 2012; 23: 623-30.

2 Johnell O, Kanis JA. An estimate of the worldwide prevalence and disability associated with osteoporotic fractures. Osteoporos Int 2006; 17: 1726-33.

3 Cooper C, Campion G, Melton LJ 3rd. Hip fractures in the elderly: a world-wide projection. Osteoporos Int 1992; 2: 285-89.

4 Tinetti ME, Speechley M, Ginter SF. Risk factors for falls among elderly persons living in the community. N Engl J Med 1988; 319: 1701-7.

5 Kannus P, Sievanen H, Palvanen M, Jarvinen T, Parkkari J. Prevention of falls and consequent injuries in elderly people. Lancet 2005; 366 : 1885-93.

6 Tinetti ME, Liu WL, Ginter SF. Mechanical restraint use and fall-related injuries among residents of skilled nursing facilities. Ann Intern Med 1992; 116: 369-74.

7 Tinetti ME, Doucette J, Claus E, Marottoli R. Risk factors for serious injury during falls by older persons in the community. J Am Geriatr Soc 1995; 43: 1214-21.

8 Fingerhut L, Warner M. Injury Chartbook. Health, United States, 1996-1997. Hyattsville, Maryland., 1997.

9 Rice D, MacKenzie E, Associates. Cost of injury in the United States: a report to congress. San Francisco: University of California, 1989.

10 Melton LJ 3rd, Riggs BL. Risk factors for injury after a fall. Clin Geriatr Med 1985; 1: 525-39.

11 Kannus P, Niemi S, Parkkari J, Palvanen M, Vuori I, Jarvinen M. Nationwide decline in incidence of hip fracture. J Bone Miner Res 2006; 21: 1836-38.

12 Cameron ID, Murray GR, Gillespie LD, Robertson MC, Hill KD, Cumming RG, Kerse N. Interventions for preventing falls in older people in nursing care facilities and hospitals. Cochrane Database Syst Rev 2010; 1: CD005465.

13 Gillespie LD, Robertson MC, Gillespie WJ, Lamb SE, Gates S, Cumming RG, Rowe BH. Interventions for preventing falls in older people living in the community. Cochrane Database Syst Rev 2009; 2: CD007146.

14 Gillespie LD, Robertson MC, Gillespie WJ, Sherrington C, Gates S, Clemson LM, Lamb SE.
Interventions for preventing falls in older people living in the community. Cochrane Database Syst Rev 2012; 9: CD007146.

15 McClure R, Turner C, Peel N, Spinks A, Eakin E, Hughes K. Population-based interventions for the prevention of fall-related injuries in older people. Cochrane Database Syst Rev 2005; 1: CD004441.

16 Karinkanta S, Piirtola M, Sievanen H, Uusi-Rasi K, Kannus P. Physical therapy approaches to reduce fall and fracture risk among older adults. Nat Rev Endocrinol 2010; 6: 396-407.

17 Lyons RA, John A, Brophy S, Jones SJ, Johansen A, Kemp A, Lannon S, Patterson J, Rolfe B, Sander LV, Weightman A. Modification of the home environment for the reduction of injuries. Cochrane Database Syst Rev 2006; 4: CD003600.

18 Oliver D, Connelly JB, Victor CR, Shaw FE, Whitehead A, Genc Y, Vanoli A, Martin FC, Gosney MA. Strategies to prevent falls and fractures in hospitals and care homes and effect of cognitive impairment: systematic review and meta-analyses. BMJ 2007; 334: 82.

19 Sherrington C, Whitney JC, Lord SR, Herbert RD, Cumming RG, Close JC. Effective exercise for the prevention of falls: a systematic review and meta-analysis. J Am Geriatr Soc 2008; 56: 2234-43.

20 Liu CJ, Latham NK. Progressive resistance strength training for improving physical function in older adults. Cochrane Database Syst Rev 2009; 3: CD002759.

21 Close J, Ellis M, Hooper R, Glucksman E, Jackson $S$, Swift C. Prevention of falls in the elderly trial (PROFET): a randomised controlled trial. Lancet 1999; 353: 93-97.

22 Campbell AJ, Robertson MC, Gardner MM, Norton RN, Buchner DM. Falls prevention over 2 years: a randomized controlled trial in women 80 years and older. Age Ageing 1999; 28: 513-18.

23 Gardner MM, Robertson MC, Campbell AJ. Exercise in preventing falls and fall related injuries in older people: a review of randomised controlled trials. Br J Sports Med 2000; 34: 7-17.

24 Gillespie LD, Gillespie WJ, Robertson MC, Lamb SE, Cumming RG, Rowe BH. Interventions for preventing falls in elderly people. Cochrane Database Syst Rev 2003; 4: CD000340.

25 Province MA, Hadley EC, Hornbrook MC, Lipsitz LA, Miller JP, Mulrow CD, Ory MG, Sattin RW, Tinetti ME, Wolf SL. The effects of exercise on falls in elderly patients. A preplanned meta-analysis of the FICSIT Trials. Frailty and Injuries: Cooperative Studies of Intervention Techniques. JAMA 1995; 273: 1341-47.

26 Karinkanta S, Heinonen A, Sievanen H, Uusi-Rasi K, Pasanen M, Ojala K, Fogelholm M, Kannus P. A multi-component exercise regimen to prevent 
functional decline and bone fragility in home-dwelling elderly women: randomized, controlled trial. Osteoporos Int 2007; 18: 453-62.

27 Barnett A, Smith B, Lord SR, Williams M, Baumand A. Community-based group exercise improves balance and reduces falls in at-risk older people: a randomised controlled trial. Age Ageing 2003; 32: 407-14.

28 Ballard JE, McFarland C, Wallace LS, Holiday DB, Roberson G. The effect of 15 weeks of exercise on balance, leg strength, and reduction in falls in 40 women aged 65 to 89 years. J Am Med Womens Assoc 2004; 59: 255-61.

29 Buchner DM, Cress ME, de Lateur BJ, Esselman PC, Margherita AJ, Price R, Wagner EH. The effect of strength and endurance training on gait, balance, fall risk, and health services use in community-living older adults. J Gerontol A Biol Sci Med Sci 1997; 52: M218-24.

30 Bunout D, Barrera G, Avendano M, de la Maza P, Gattas V, Leiva L, Hirsch S. Results of a community-based weight-bearing resistance training programme for healthy Chilean elderly subjects. Age Ageing 2005; 34: 80-83.

31 Carter ND, Khan KM, McKay HA, Petit MA, Waterman C, Heinonen A, Janssen PA, Donaldson MG, Mallinson A, Riddell L, Kruse K, Prior JC, Flicker L. Community-based exercise program reduces risk factors for falls in 65- to 75-year-old women with osteoporosis: randomized controlled trial. CMAJ 2002; 167: 997-1004.

32 Korpelainen R, Keinanen-Kiukaanniemi S, Heikkinen J, Vaananen K, Korpelainen J. Effect of impact exercise on bone mineral density in elderly women with low BMD: a population-based randomized controlled 30-month intervention. Osteoporos Int 2006; 17: 109-18.

33 Lord SR, Castell S, Corcoran J, Dayhew J, Matters $\mathrm{B}$, Shan A, Williams P. The effect of group exercise on physical functioning and falls in frail older people living in retirement villages: a randomized, controlled trial. J Am Geriatr Soc 2003; 51: 1685-92.

34 Lord SR, Ward JA, Williams P, Strudwick M. The effect of a 12-month exercise trial on balance, strength, and falls in older women: a randomized controlled trial. J Am Geriatr Soc 1995; 43: 1198-206.

35 Means KM, Rodell DE, O’Sullivan PS. Balance, mobility, and falls among community-dwelling elderly persons: effects of a rehabilitation exercise program. Am J Phys Med Rehabil 2005; 84: $238-50$.

36 Luukinen H, Lehtola S, Jokelainen J, Vaananen-Sainio R, Lotvonen S, Koistinen P. Pragmatic exercise-oriented prevention of falls among the elderly: a population-based, randomized, controlled trial. Prev Med 2007; 44:

265-71.

37 Rubenstein LZ, Josephson KR, Trueblood PR, Loy S, Harker JO, Pietruszka FM, Robbins AS. Effects of a group exercise program on strength, mobility, and falls among fall-prone elderly men. J Gerontol A Biol Sci Med Sci 2000; 55: M317-21.

38 Skelton D, Dinan S, Campbell M, Rutherford O. Tailored group exercise (Falls Management Exercise - FaME) reduces falls in community-dwelling older frequent fallers (an RCT). Age Ageing 2005; 34: 636-39.

39 Campbell AJ, Robertson MC, Gardner MM, Norton RN, Tilyard MW, Buchner DM.

Randomised controlled trial of a general practice programme of home based exercise to prevent falls in elderly women. BMJ 1997; 315: 1065-69.

40 Weerdesteyn V, Rijken H, Geurts AC, Smits-Engelsman BC, Mulder T, Duysens J. A five-week exercise program can reduce falls and improve obstacle avoidance in the elderly. Gerontology 2006; 52: 131-41.

41 Lin MR, Wolf SL, Hwang HF, Gong SY, Chen CY. A randomized, controlled trial of fall prevention programs and quality of life in older fallers. J Am Geriatr Soc 2007; 55: 499_ 506.

42 Suzuki T, Kim H, Yoshida H, Ishizaki T. Randomized controlled trial of exercise intervention for the prevention of falls in community-dwelling elderly Japanese women. J Bone Miner Metab 2004; 22: 602-11.

43 Robertson MC, Devlin N, Scuffham P, Gardner MM, Buchner DM, Campbell AJ. Economic evaluation of a community based exercise programme to prevent falls. J Epidemiol Community Health 2001; 55: 600-6.

44 Li F, Harmer P, Fisher KJ, McAuley E, Chaumeton N, Eckstrom E, Wilson NL. Tai Chi and fall reductions in older adults: a randomized controlled trial. J Gerontol A Biol Sci Med Sci 2005; 60:187-94.

45 Wolf SL, Barnhart HX, Kutner NG, McNeely E, Coogler C, Xu T. Reducing frailty and falls in older persons: an investigation of Tai Chi and computerized balance training. Atlanta FICSIT Group. Frailty and Injuries: Cooperative Studies of Intervention Techniques. J Am Geriatr Soc 1996; 44: 489-97.

46 Wolf SL, Sattin RW, Kutner M, O'Grady M, Greenspan AI, Gregor RJ. Intense tai chi exercise training and fall occurrences in older, transitionally frail adults: a randomized, controlled trial. J Am Geriatr Soc 2003; 51: 1693-701.

47 Cornillon E, Blanchon MA, Ramboatsisetraina P, Braize C, Beauchet O, Dubost V, Blanc P, 
Gonthier R. [Effectiveness of falls prevention strategies for elderly subjects who live in the community with performance assessment of physical activities (before-after)]. Ann Readapt Med Phys 2002; 45: 493-504.

48 McMurdo ME, Mole PA, Paterson CR. Controlled trial of weight bearing exercise in older women in relation to bone density and falls. BMJ 1997; 314: 569.

49 Liu-Ambrose T, Khan KM, Eng JJ, Lord SR, McKay HA. Balance confidence improves with resistance or agility training. Increase is not correlated with objective changes in fall risk and physical abilities. Gerontology 2004; 50: 373-82.

50 Davis JC, Robertson MC, Ashe MC, Liu-Ambrose T, Khan KM, Marra CA. Does a home-based strength and balance programme in people aged > or $=80$ years provide the best value for money to prevent falls? A systematic review of economic evaluations of falls prevention interventions. $\mathrm{Br} J$ Sports Med 2010; 44: 80-89.

51 Frick KD, Kung JY, Parrish JM, Narrett MJ. Evaluating the cost-effectiveness of fall prevention programs that reduce fall-related hip fractures in older adults. J Am Geriatr Soc 2010; 58:136-41.

52 Wolf SL, Barnhart HX, Ellison GL, Coogler CE. The effect of Tai Chi Quan and computerized balance training on postural stability in older subjects. Atlanta FICSIT Group. Frailty and Injuries: Cooperative Studies on Intervention Techniques. Phys Ther 1997; 77: 371-81; discussion 82-84.

53 Voukelatos A, Cumming RG, Lord SR, Rissel C. A randomized, controlled trial of tai chi for the prevention of falls: the Central Sydney tai chi trial. J Am Geriatr Soc 2007; 55: 1185-91.

54 Clemson L, Fiatarone Singh MA, Bundy A, Cumming RG, Manollaras K, O’Loughlin P, Black D. Integration of balance and strength training into daily life activity to reduce rate of falls in older people (the LiFE study): randomised parallel trial. BMJ 2012; 345: e4547.

55 Trombetti A, Hars M, Herrmann FR, Kressig RW, Ferrari S, Rizzoli R. Effect of music-based multitask training on gait, balance, and fall risk in elderly people: a randomized controlled trial. Arch Internal Med 2011; 171: 525-33.

56 Mulrow CD, Gerety MB, Kanten D, Cornell JE, DeNino LA, Chiodo L, Aguilar C, O’Neil MB, Rosenberg J, Solis RM. A randomized trial of physical rehabilitation for very frail nursing home residents. JAMA 1994; 271: 519-24.

57 Faber MJ, Bosscher RJ, Chin APMJ, van Wieringen PC. Effects of exercise programs on falls and mobility in frail and pre-frail older adults: A multicenter randomized controlled trial. Arch Phys Med Rehabil 2006; 87: 885-96.
58 Rosendahl E, Gustafson Y, Nordin E, Lundin-Olsson L, Nyberg L. A randomized controlled trial of fall prevention by a high-intensity functional exercise program for older people living in residential care facilities. Aging Clin Exp Res 2008; 20: 67-75.

59 Schoenfelder DP. A fall prevention program for elderly individuals. Exercise in long-term care settings. J Gerontol Nurs 2000; 26: 43-51.

60 Sakamoto K, Nakamura T, Hagino H, Endo N, Mori S, Muto Y, Harada A, Nakano T, Itoi E, Yoshimura M, Norimatsu H, Yamamoto H, Ochi T. Effects of unipedal standing balance exercise on the prevention of falls and hip fracture among clinically defined high-risk elderly individuals: a randomized controlled trial. J Orthop Sci 2006; 11: 467-72.

61 Shimada H, Obuchi S, Furuna T, Suzuki T. New intervention program for preventing falls among frail elderly people: the effects of perturbed walking exercise using a bilateral separated treadmill. Am J Phys Med Rehabil 2004; 83 : 493-99.

62 Sihvonen S, Sipila S, Taskinen S, Era P. Fall incidence in frail older women after individualized visual feedback-based balance training. Gerontology 2004; 50: 411-16.

63 Latham NK, Anderson CS, Lee A, Bennett DA, Moseley A, Cameron ID. A randomized, controlled trial of quadriceps resistance exercise and vitamin D in frail older people: the Frailty Interventions Trial in Elderly Subjects (FITNESS). J Am Geriatr Soc 2003; 51: 291-99.

64 Porthouse J, Cockayne S, King C, Saxon L, Steele E, Aspray T, Baverstock M, Birks Y, Dumville J, Francis R, Iglesias C, Puffer S, Sutcliffe A, Watt I, Torgerson DJ. Randomised controlled trial of calcium and supplementation with cholecalciferol (vitamin D3) for prevention of fractures in primary care. BMJ 2005; 330: 1003.

65 Bischoff-Ferrari HA, Orav EJ, Dawson-Hughes B. Effect of cholecalciferol plus calcium on falling in ambulatory older men and women: a 3-year randomized controlled trial. Arch Intern Med 2006; 166: 424-30.

66 Pfeifer M, Begerow B, Minne HW, Abrams C, Nachtigall D, Hansen C. Effects of a short-term vitamin $\mathrm{D}$ and calcium supplementation on body sway and secondary hyperparathyroidism in elderly women. J Bone Miner Res 2000; 15: 1113-18.

67 Gallagher JC, Fowler SE, Detter JR, Sherman SS, Combination treatment with estrogen and calcitriol in the prevention of age-related bone loss. J Clin Endocrinol Metab 2001; 86: 3618-28.

68 Dhesi JK, Jackson SH, Bearne LM, Moniz C, Hurley MV, Swift CG, Allain TJ. Vitamin D 
supplementation improves neuromuscular function in older people who fall. Age Ageing 2004; 33: 589-95.

69 Sato Y, Manabe S, Kuno H, Oizumi K. Amelioration of osteopenia and hypovitaminosis D by 1alpha-hydroxyvitamin D3 in elderly patients with Parkinson's disease. I Neurol Neurosurg Psychiatry 1999; 66: 64-68.

70 Sato Y, Kaji M, Oizomi K. An alternative to vitamin D supplementation to prevent fractures in patients with MS. Neurology 1999; 53: 437.

71 Pit SW, Byles JE, Henry DA, Holt L, Hansen V, Bowman DA. A Quality Use of Medicines program for general practitioners and older people: a cluster randomised controlled trial. Med J Aust 2007; 187: 23-30.

72 Kenny RA, Richardson DA, Steen N, Bexton RS, Shaw FE, Bond J. Carotid sinus syndrome: a modifiable risk factor for nonaccidental falls in older adults (SAFE PACE). J Am Coll Cardiol 2001; 38: 1491-96.

73 Harwood RH, Foss AJ, Osborn F, Gregson RM, Zaman A, Masud T. Falls and health status in elderly women following first eye cataract surgery: a randomised controlled trial. $\mathrm{Br} \mathrm{J} \mathrm{Ophthalmol}$ 2005; 89: 53-59.

74 Foss AJ, Harwood RH, Osborn F, Gregson RM, Zaman A, Masud T. Falls and health status in elderly women following second eye cataract surgery: a randomised controlled trial. Age Ageing 2006; 35: 66-71.

75 Stevens M, Holman CD, Bennett N. Preventing falls in older people: impact of an intervention to reduce environmental hazards in the home. $\mathrm{J} \mathrm{Am}$ Geriatr Soc 2001; 49: 1442-47.

76 Pighills AC, Torgerson DJ, Sheldon TA, Drummond AE, Bland JM. Environmental assessment and modification to prevent falls in older people. J Am Geriatr Soc 2011; 59: 26-33.

77 Cumming RG, Ivers R, Clemson L, Cullen J, Hayes MF, Tanzer M, Mitchell P. Improving vision to prevent falls in frail older people: a randomized trial. J Am Geriatr Soc 2007; 55: 175-81.

78 Campbell AJ, Robertson MC, La Grow SJ, Kerse NM, Sanderson GF, Jacobs RJ, Sharp DM, Hale LA. Randomised controlled trial of prevention of falls in people aged $>$ or $=75$ with severe visual impairment: the VIP trial. BMJ 2005; 331: 817.

79 Cumming RG, Thomas M, Szonyi G, Salkeld G, O’Neill E, Westbury C, Frampton G. Home visits by an occupational therapist for assessment and modification of environmental hazards: a randomized trial of falls prevention. J Am Geriatr Soc 1999; 47: 1397-402.

80 Day L, Fildes B, Gordon I, Fitzharris M, Flamer $\mathrm{H}$, Lord S. Randomised factorial trial of falls prevention among older people living in their own homes. BMJ 2002; 325: 128.

81 Menant JC, Steele JR, Menz HB, Munro BJ, Lord SR. Optimizing footwear for older people at risk of falls. J Rehabil Res Dev 2008; 45: 1167-81.

82 McKiernan FE. A simple gait-stabilizing device reduces outdoor falls and nonserious injurious falls in fall-prone older people during the winter. J Am Geriatr Soc 2005; 53: 943-47.

83 Spink MJ, Menz HB, Fotoohabadi MR, Wee E, Landorf KB, Hill KD, Lord SR. Effectiveness of a multifaceted podiatry intervention to prevent falls in community dwelling older people with disabling foot pain: randomised controlled trial. BMJ 2011; 342: 3411.

84 Hill S, Mossman J, Stockdale P, Crome P. A randomised controlled trial of a nurse-led falls prevention clinic. Age Ageing 2000; 29 (suppl 2): 20.

85 Clemson L, Cumming RG, Kendig H, Swann M, Heard R, Taylor K. The effectiveness of a community-based program for reducing the incidence of falls in the elderly: a randomized trial. J Am Geriatr Soc 2004; 52: 1487-94.

86 Shumway-Cook A, Silver IF, LeMier M, York S, Cummings P, Koepsell TD. Effectiveness of a community-based multifactorial intervention on falls and fall risk factors in community-living older adults: a randomized, controlled trial. I Gerontol A Biol Sci Med Sci 2007; 62: 1420-27.

87 Swanenburg J, de Bruin ED, Stauffacher M, Mulder T, Uebelhart D. Effects of exercise and nutrition on postural balance and risk of falling in elderly people with decreased bone mineral density: randomized controlled trial pilot study. Clin Rehabil 2007; 21: 523-34.

88 Assantachai P, Chatthanawaree W, Thamlikitkul V, Praditsuwan R, Pisalsarakij D. Strategy to prevent falls in the Thai elderly: a controlled study integrated health research program for the Thai elderly. J Med Assoc Thai 2002; 85: 215-22.

89 Davison J, Bond J, Dawson P, Steen IN, Kenny RA. Patients with recurrent falls attending Accident \& Emergency benefit from multifactorial intervention-a randomised controlled trial. Age Ageing 2005; 34: 162-68.

90 Hornbrook MC, Stevens VJ, Wingfield DJ, Hollis JF, Greenlick MR, Ory MG. Preventing falls among community-dwelling older persons: results from a randomized trial. Gerontologist 1994; 34 : 16-23.

91 Lord SR, Tiedemann A, Chapman K, Munro B, Murray SM, Gerontology M, Ther GR, Sherrington C. The effect of an individualized fall prevention program on fall risk and falls in older people: a randomized, controlled trial. J Am Geriatr Soc 2005; 53: 1296-304. 
92 Tinetti ME, Baker DI, McAvay G, Claus EB, Garrett P, Gottschalk M, Koch ML, Trainor K, Horwitz RI. A multifactorial intervention to reduce the risk of falling among elderly people living in the community. N Engl J Med 1994; 331: 821-27.

93 Salminen MJ, Vahlberg TJ, Salonoja MT, Aarnio PT, Kivelä S-L. Falls data (as supplied 20 May 2008) - unpublished data. Data on file. 2008.

94 Wyman J, Gross C, DiFabio R, Nyman J, Lindquist R, McCarthy T. A randomized trial of exercise, education, and risk reduction counseling to prevent falls in populationbased sample of older women. Gerontologist 2005; 45 (Special Issue II): 297.

95 Carpenter GI, Demopoulos GR. Screening the elderly in the community: controlled trial of dependency surveillance using a questionnaire administered by volunteers. BMJ 1990; 300: 1253-56.

96 Gallagher EM, Brunt H. Head over heels: impact of a health promotion program to reduce falls in the elderly. Canadian J Aging 1996; 15: 84-96.

97 Hogan DB, MacDonald FA, Betts J, Bricker S, Ebly EM, Delarue B, Fung TS, Harbidge C,
Hunter M, Maxwell CJ, Metcalf B. A randomized controlled trial of a community-based consultation service to prevent falls. CMAJ 2001; 165 : 537-43.

98 Lightbody E, Watkins C, Leathley M, Sharma A, Lye M. Evaluation of a nurse-led falls prevention programme versus usual care: a randomized controlled trial. Age Ageing 2002; 31: 203-10.

99 Mahoney JE, Shea TA, Przybelski R, Jaros L, Gangnon R, Cech S, Schwalbe A. Kenosha County falls prevention study: a randomized, controlled trial of an intermediate-intensity, community-based multifactorial falls intervention. J Am Geriatr Soc 2007; 55: 489-98.

100 Rubenstein LZ, Alessi CA, Josephson KR, Trinidad Hoyl M, Harker JO, Pietruszka FM. A randomized trial of a screening, case finding, and referral system for older veterans in primary care. J Am Geriatr Soc 2007; 55: 166-74.

101 Elley CR, Robertson MC, Garrett S, Kerse NM, McKinlay E, Lawton B, Moriarty H, Moyes SA, Campbell AJ. Effectiveness of a falls-and-fracture nurse coordinator to reduce falls: a randomized, controlled trial of at-risk older adults. $\mathrm{J} \mathrm{Am}$ Geriatr Soc 2008; 56: 1383-89. 